\title{
Molecular identification of Lodoicea maldivica (coco de mer) seeds
}

\author{
Chun-yin Mak ${ }^{*}$ and Chuen-shing Mok
}

\begin{abstract}
Background: The edible endosperm of Lodoicea maldivica with the common name of coco de mer is used in Chinese medicine for treating cough. Native to Seychelles, Lodoicea maldivica seeds have commanded high prices for centuries due to its scarcity. This study aims to develop a molecular identification method for the authentication of Lodoicea maldivica seeds.
\end{abstract}

Methods: DNA was extracted from the sample. Two polymerase chain reaction (PCR) systems were developed to amplify a region of the chloroplast DNA and the nuclear phosphoribulokinase (PRK) region specific to Lodoicea maldivica respectively. DNA sequence of a sample was determined and compared with that of the Lodoicea maldivica reference material.

Results: The PRK gene of Lodoicea maldivica was successfully amplified and sequenced for identification.

Conclusion: A new molecular method for the identification of Lodoicea maldivica seeds in fresh, frozen or dried forms was developed.

\section{Background}

Lodoicea maldivica (coco de mer), the sole member of the genus Lodoicea, is a fan-leaved palm native to Seychelles, bearing the largest and heaviest seed in the plant kingdom (weighing up to $30 \mathrm{~kg}$ ). The seed is enclosed in a hard shell resembling a pair of coconuts joined in the middle. The seed is sometimes also referred to as the sea coconut, bum seed, double coconut, coco fesse or Seychelles nut. Lodoicea maldivica palms take between 25-50 years to reach maturity and bear fruit. The fruit may take one to three years to germinate [1]. Only two natural populations of Lodoicea maldivica remain [1]. Individual plants are also cultivated in various botanical gardens around the world. The harvest of seeds has virtually stopped all natural regeneration of the plant. The populations are also threatened by fire and encroachment by invasive plants. In March 2010, Lodoicea maldivica was added to the appendices of the Convention on International Trade in Endangered Species of Wild Fauna and Flora (CITES) in its $15^{\text {th }}$ meeting of the Conference of the Parties [2]. Trade of Lodoicea maldivica is also governed by the Protection of Endangered

\footnotetext{
* Correspondence: cymak@govtlab.gov.hk

Government Laboratory Hong Kong, 7/F Ho Man Tin Government Offices, 88 Chung Hau Street, Kowloon, Hong Kong SAR, China
}

Species of Animals and Plants Ordinance in Hong Kong (Cap. 586). According to the ordinance, unless exempted, the import, introduction from the sea, export, re-export or possession of Lodoicea maldivica requires a licence issued by the Hong Kong government. The edible endosperm (ie fruit) of the plant has long been used in Chinese medicine for treating cough and is used mainly in soup in Hong Kong, China [3]. As fake products are often found in the markets, an identification method is needed.

This study aims to develop a new method for the identification of Lodoicea maldivica with DNA sequencing analysis. DNA was extracted from the edible endosperm sample. A polymerase chain reaction (PCR) system was designed to amplify a region of the chloroplast DNA to validate the quality of the extracted DNA $[4,5]$. A number of genes or spacer regions may be considered to identify unknown samples, for example, the internal transcribed spacer 1 [6], internal transcribed spacer 2 [6], nuclear ribosomal RNA genes $18 \mathrm{~S}$ unit [6], large subunit of ribulose 1,5-bisphosphate carboxylase/oxygenase $(r b c L)$ [7], intergenic region between the $\beta$ subunit of ATP synthase $(a t p B)$ and $r b c L$ [8] and the chloroplast trnL-trnF intergenic spacer region [9]. In this study, a PCR system targeting the nuclear phosphoribulokinase (PRK) region was
C Biomed Central 
designed. This region has been employed in many palm phylogenetics and shown ample characters to resolve relations at species level [10-13]. After DNA sequence analysis, the identity of the unknown was evaluated by pair-wise matching of its sequence with that of the certified Lodoicea maldivica reference species.

\section{Methods}

\section{Materials}

A Lodoicea maldivica seed certified by the Ministry of Environment, Natural Resources and Transport of the Republic of Seychelles was used as reference. The official certificate supports the authenticity of the species. The fresh reference seed is, thick, relatively hard and brown in colour with white flesh inside and about $10 \mathrm{~kg}$ in weight. The seed was assigned a voucher number of TD/TD/CRM/10001. The seed was kept frozen before analysis. Seven sliced commercial products with description of sea coconut or coco de mer (namely Sample A to Sample G) and one coconut sample (sample H) were purchased from the local market. Sample details are listed in Table 1

For the samples in the form of pre-packaged product mixed with other materials, the suspected coconut portion was isolated from the background matrix before homogenisation. For fresh/frozen samples, the sample was homogenised by a blender, and about $1-5 \mathrm{~g}$ of the sample was transferred into a flat bottom glass container. The sample was freeze-dried. The dried sample was ground into fine powder in liquid nitrogen. For dried samples, the sample was simply ground into fine powder in liquid nitrogen.

\section{DNA extraction}

DNA extraction was performed with the CTAB method [14]. A total of $1.0 \mathrm{~mL}$ of pre-warmed $\left(65^{\circ} \mathrm{C}\right) \mathrm{CTAB}$ extraction buffer $(2 \% \mathrm{w} / \mathrm{v}$ hexadecyl trimethylammonium bromide (CTAB), $0.1 \mathrm{M}$ Tris, $1.4 \mathrm{M} \mathrm{NaCl}, 20 \mathrm{mM}$ EDTA) was added to $100 \mathrm{mg}$ of the test sample in a $2.0 \mathrm{~mL}$ microcentrifuge tube. Alpha-amylase solution $(10 \mu \mathrm{L}-20 \mu \mathrm{L})$, $20 \mu \mathrm{L}$ of proteinase $\mathrm{K}$ solution $(20 \mathrm{mg} / \mathrm{mL}), 100 \mu \mathrm{L}$ of $10 \%$ w/v polyvinylpolypyrrolidone (PVP) and $5 \mu \mathrm{L}$ of RNase A $(100 \mathrm{mg} / \mathrm{mL})$ were added. The mixture was incubated at $65^{\circ} \mathrm{C}$ overnight with constant agitation. After centrifugation (Eppendorf, Germany) for ten minutes at $16,000 \times \mathrm{g}$ at room temperature, the supernatant was transferred to a new $2.0 \mathrm{~mL}$ tube and an equal amount of chloroform was added. The sample was shaken vigorously for 30 seconds before centrifugation (Eppendorf, Germany) for ten minutes at $16,000 \times \mathrm{g}$ at room temperature. The upper layer was transferred to a new $2.0 \mathrm{~mL}$ tube and extracted with an equal amount of chloroform. The sample was centrifuged 16,000× g (Eppendorf, Germany) for five minutes. The upper layer was transferred to a new $2.0 \mathrm{~mL}$ tube and two volumes of CTAB precipitation solution $(0.5 \% \mathrm{w} / \mathrm{v}$ CTAB, $0.04 \mathrm{M} \mathrm{NaCl}$ ) were added. The sample was incubated at room temperature for 60 minutes without agitation. The supernatant was discarded after the sample was centrifuged (Eppendorf, Germany) for ten minutes at $16,000 \times$ g. The precipitate was dissolved in $350 \mu \mathrm{L}$ of $1.2 \mathrm{M} \mathrm{NaCl}$ solution and was centrifuged (Eppendorf, Germany) for ten minutes at $16,000 \times$ g. The upper layer was transferred to a new $1.5 \mathrm{~mL}$ tube. Two volumes of cold absolute ethanol were added to precipitate the DNA. The sample was kept at $-20^{\circ} \mathrm{C}$ for at least 20 minutes. The supernatant was discarded after centrifugation (Eppendorf, Germany) for ten minutes at $16,000 \times \mathrm{g}$ at $4^{\circ} \mathrm{C}$. A total of $500 \mu \mathrm{L}$ of $70 \%$ cold ethanol solution was added and the sample was centrifuged (Eppendorf, Germany) for ten minutes at $16,000 \times \mathrm{g}$ at $4{ }^{\circ} \mathrm{C}$. The DNA pellet was dried in a $37^{\circ} \mathrm{C}$ oven for several minutes and was then re-dissolved in $100 \mu \mathrm{L}$ of DNase-free water.

\section{PCR for chloroplast DNA}

The chloroplast DNA region (partial) was amplified with $50 \mathrm{ng}$ DNA template, $1.0 \mu \mathrm{L}$ of $5 \mathrm{mM}$ dNTPs, $0.5 \mu \mathrm{L}$ of $25 \mathrm{mM} \mathrm{MgCl}_{2}, 2.5 \mu \mathrm{L}$ of $10 \times$ PCR buffer plus $\mathrm{MgCl}_{2}$ (Applied Biosystems, USA), $0.5 \mu \mathrm{L}$ of $10 \mu \mathrm{M}$ specific primers (Table 2) and $1 \mathrm{U}$ of AmpliTaq Gold polymerase (Applied Biosystems, USA). Water was added to make up to $25 \mu \mathrm{L}$. The DNA template was denatured at $95^{\circ} \mathrm{C}$ for five minutes and then 35 cycles of 30 seconds at $94^{\circ} \mathrm{C}, 30$ seconds at $55^{\circ} \mathrm{C}, 45$ seconds at $72^{\circ} \mathrm{C}$ and final extension at $72^{\circ} \mathrm{C}$ for five minutes. The amplification products were electrophoresed on a $1 \%$ agarose gel, stained with ethidium bromide and observed under UV illumination.

\section{PCR for PRK gene}

The PRK gene was amplified with 50 ng DNA template, $1.25 \mu \mathrm{L}$ of $5 \mathrm{mM}$ dNTPs, $2.0 \mu \mathrm{L}$ of $25 \mathrm{mM} \mathrm{MgCl}_{2}$, $2.5 \mu \mathrm{L}$ of $10 \times$ PCR buffer without $\mathrm{MgCl}_{2}$ (Applied

Table 1 Sample information and the results of their identities found

\begin{tabular}{llll}
\hline Sample code & $\begin{array}{l}\text { Sample description } \\
\text { (form) }\end{array}$ & Target region & Percentage identity \\
\hline Sample A & African seacoconut (dried) & PRK & 99\% [GenBank: (AF453357)] \\
Sample H & Coconut (fresh) & PRK & $100 \%$ \\
& & [GenBank: (HQ265608)] \\
\hline
\end{tabular}


Table 2 Nucleotide sequences of specific primers used for the amplification of the chloroplast DNA and PRK gene

\begin{tabular}{llll}
\hline Name & Oligonucleotide DNA sequence $\left.\mathbf{( 5}^{\prime} \mathbf{- 3} \mathbf{3}^{\prime}\right)$ & Amplicon size & Specificity \\
\hline Plant 1 (forward) & CGA AAT CGG TAG ACG CTA CG & 550 bp & Chloroplast DNA \\
Plant 2 (reverse) & GGG GAT AGA GGG ACT TGA AC & \\
prk717f (forward) & GTG ATA TGG AAG AAC GTG G & 750 bp & PRK gene \\
prk969r (reverse) & ATT CCA GGG TAT GAG CAG C & & \\
\hline
\end{tabular}

Biosystems, USA), $1.5 \mu \mathrm{L}$ of $10 \mu \mathrm{M}$ specific primers (Table 2), $1.25 \mu \mathrm{L}$ of $40 \mathrm{ng} / \mu \mathrm{L}$ bovine serum albumin (BSA), $0.5 \mu \mathrm{L}$ of dimethyl sulfoxide (DMSO) and $1 \mathrm{U}$ of AmpliTaq Gold polymerase (Applied Biosystems, USA). Water was added to make up the final volume to $25 \mu \mathrm{L}$. The DNA template was denatured at $95^{\circ} \mathrm{C}$ for four minutes, and then 35 cycles of one minute at $94^{\circ} \mathrm{C}, 30 \mathrm{sec}-$ onds at $54^{\circ} \mathrm{C}$, one minute at $72^{\circ} \mathrm{C}$ and final extension at $72^{\circ} \mathrm{C}$ for seven minutes. The amplification products were electrophoresed on a $1 \%$ agarose gel, stained with ethidium bromide and observed under UV illumination.

\section{DNA sequencing}

The PCR products of PRK gene were purified with DNA Clean \& Concentrator ${ }^{\mathrm{TM}}-25$ (Zymo Research, USA) according to the manufacturer's instructions. The BigDye ${ }^{\circledR}$ Terminator v3.1 Cycle Sequencing Kit (Applied Biosystems, USA) was used for the cycle sequencing reaction. The PCR product was first denatured at $96^{\circ} \mathrm{C}$ for one minute and then 25 cycles of thermal cycling was performed as follows: $96^{\circ} \mathrm{C}$ for ten seconds, $50^{\circ} \mathrm{C}$ for five seconds, $60^{\circ} \mathrm{C}$ for four minutes. The BigDye ${ }^{\circledR}$ XTerminator ${ }^{\mathrm{TM}}$ Purification Kit (Applied Biosystems, USA) was used to purify the extension products according to the manufacturer's instructions and the products were then run on the ABI PRISM $^{\circledR}$ 3130XL Genetic Analyzer (Applied Biosystems, USA).

\section{Sequence Analysis}

We aligned the sequence of the unknown sample in pair with that of the reference species using the bl2seq tool of the National Center for Biotechnology Information (NCBI) website [15]. Moreover, we performed multiple sequence alignment using the CLUSTAL2 tool of the European Bioinformatics Institute website [16].

\section{Results and Discussion DNA extraction}

A study [17] reported that DNA from the solid endosperm of coconut was not a good starting material for molecular biology work because the matrix may hinder enzyme activity and because of the high lipid and polysaccharide content. The study suggested that DNA from young leaves of the plant should be used as the source of genomic DNA. Nevertheless, only the edible endosperm of Lodoicea maldivica is used in Chinese medicine and the commercial products thereof are made up of various forms of its edible endosperm. In order to develop a method for testing the authenticity of the claimed Lodoicea maldivica products, we think that PCR-ready DNA must be extracted from the endosperm of Lodoicea maldivica.

The chemical PVP is an important reagent in DNA extraction. Without the addition of PVP, the sample solution for the extracted DNA contained high levels of polysaccharide, as shown in the UV spectra. The contamination was greatly reduced by the addition of PVP during the initial incubation at $65^{\circ} \mathrm{C}$ in the extraction step. While the amount of DNA extracted from all samples in this study was very low $(<10 \mathrm{ng} / \mu \mathrm{L})$, the quality of the extracted genomic DNA was sufficient for the PCR and sequencing.

\section{PCR-chloroplast DNA}

Plant 1 and Plant 2 primers are targeted for the amplification of a region of plant chloroplast DNA and were used to verify the quality of the template DNA [2]. A single PCR product of about $550 \mathrm{bp}$ was successfully amplified from all samples. The positive PCR results indicated that DNA of sufficient quantity and quality were successfully extracted and that the PCR was not inhibited by other components of the analytical sample.

\section{PCR PRK gene}

The nuclear region of the PRK gene was amplified with the second PCR system. This region has been used successfully to resolve palm phylogenetic relations at the species level [10-13]. Positive results (ie a fluorescent DNA band of about $750 \mathrm{bp}$ ) from this PCR system would indicate that the sample contained the PRK gene whereas negative results would indicate that the sample was not from Lodoicea maldivica.

Single-band PCR products of about 750 bp were successfully amplified from Lodoicea maldivica reference material and two commercial products namely Sample A and Sample H. Other samples yielded either negative results or multiple PCR products in the amplification of PRK gene. Lodoicea maldivica yielded only one single PCR product in the analysis of PRK gene. The sample should be considered as not of Lodoicea maldivica in origin when no or more than one band was observed after agarose gel electrophoresis [4]. The identities of these 
unknown samples were found by using one of the markers [6-9] as mentioned in the background section.

\section{Sequence analysis}

All the amplified PRK genes were successfully sequenced. The nucleotide sequence of the Lodoicea maldivica reference material was submitted to the GenBank [GenBank: JF820816]. We compared the nucleotide sequence in pair between the reference material and each of the unknown samples using the bl2seq tool [15]. For those sequences not matching the reference material, further search in the GenBank was performed. The PRK gene sequence of sample A was identical to that of the reference material (Figure 1). While the PRK gene sequence of sample $\mathrm{H}$ only matched that of the reference material with $80 \%$

\begin{tabular}{|c|c|c|}
\hline \multirow{2}{*}{$\begin{array}{l}\text { AF453357 } \\
\text { Sample_A } \\
\text { Lodoicea_maldivica_RM }\end{array}$} & \multicolumn{2}{|l|}{$\begin{array}{l}\text { GTCTTGACAGCATCAAAGCTAGCATTGAAGCTCGAAAGCCTGATTTTGAT } 50 \\
- \text { GCCTGATTTTGAT } 13\end{array}$} \\
\hline & & \\
\hline AF453357 & GCTTATGTTGGTATGTCACCTTGCCCCAGCACCTAGTTGTTAGTACTTGA & 100 \\
\hline Sample_A & GCTTATGTTGGTATGTCACCTTGCCCCAGCACCTAGTTGTTAGTACTTGA & 63 \\
\hline AF453357 & AGAATTGGCAGTGCACTTATTTGTTGGTGTAATATAGAGCATTGCCATTA & 150 \\
\hline Sample_A & AGAATTGGCAGTGCACTTATTTGTTGGTGTAATATAGAGCATTGCCATTA & 113 \\
\hline Lodoicea_maldivica_RM & $\begin{array}{l}\text {-GGCAGTGCACTTATTTGTTGGTGTAATATAGAGCATTGCCATTA } \\
* * * * * * * * * * * * * * * * * * * * * * * * * * * * * * * * * * * * * * * * * * * *\end{array}$ & 44 \\
\hline AF453357 & GTGGTGATTGATATATATAGTAATCTACTTCTATATATAGCAAATGCTTC & 200 \\
\hline Sample_A & GTGGTGATTGATATATATAGTAATCTACTTCTATATATAGCAAATGCTTC & 163 \\
\hline Lodoicea_maldivica_RM & $\begin{array}{l}\text { GTGGTGATTGATATATATAGTAATCTACTTCTATATATAGCAAATGCTTC } \\
* * * * * * * * * * * * * * * * * * * * * * * * * * * * * * * * * * * * * * * * * * * * * * * * * *\end{array}$ & 94 \\
\hline AF453357 & ATAAATAAACTAACCTAATAAACAAAGGATCTGATCGATAA--GTCAAAT & 248 \\
\hline Sample_A & ATAAATAAACTAACCTAATAAACAAAGGATCTGATCGATAAAGGTCAAAT & 213 \\
\hline Lodoicea_maldivica_RM & $\begin{array}{l}\text { ATAAATAAACTAACCTAATAAACAAAGGATCTGATCGATAAAGGTCAAAT } \\
* * * * * * * * * * * * * * * * * * * * * * * * * * * * * * * * * * * * * * * * * * * * * * *\end{array}$ & 144 \\
\hline AF453357 & AATGCACAAAACATACTGGACTCAAAATATACTCTTACTTCATGTGCAAT & 298 \\
\hline Sample_A & AATGCACAAAACATACTGGACTCAAAATATACTCTTACTTCATGTGCAAT & 263 \\
\hline Lodoicea_maldivica_RM & 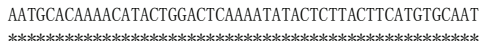 & 194 \\
\hline & & \\
\hline AF453357 & TTTTGTTGACACCTGTTTTTTTCAAAAAAAGAAAGGAGAGGAGGGGAGGG & 348 \\
\hline Sample_A & TTTTGTTGACACCTGTTTTTTTCAAAAAAAGAAAGGAGAGGAGGGGAGGG & 313 \\
\hline Lodoicea_maldivica_RM & $\begin{array}{l}\text { TTTTGTTGACACCTGTTTTTTCAAAAAAAGAAAGGAGAGGAGGGGAGG } \\
* * * * * * * * * * * * * * * * * * * * * * * * * * * * * * * * * * * * * * * * * * * * * * * *)\end{array}$ & 244 \\
\hline AF453357 & TGAGAGTCACCTGATTCATTGAAATAATGAGACAAGTAGATATGTTGCAT & 398 \\
\hline Sample_A & TGAGAGTCACCTGATTCATTGAAATAATGAGACAAGTAGATATGTTGCAT & 363 \\
\hline Lodoicea_maldivica_RM & $\begin{array}{l}\text { TGAGAGTCACCTGATTCATTGAAATAATGAGACAAGTAGTTATGTTCAT } \\
* * * * * * * * * * * * * * * * * * * * * * * * * * * * * * * * * * * * * * * * * * * * * * * * * * * *)\end{array}$ & 294 \\
\hline AF453357 & CTCATGTTCTTCAGATATCTGAATATCCATTCTTTCTTTAGCACTCTTGG & 448 \\
\hline Sample_A & CTCATGTTCTTCAGATATCTGAATATCCATTCTTTCTTTAGCACTCTTGG & 413 \\
\hline Lodoicea_maldivica_RM & $\begin{array}{l}\text { СTCATGTTCTTCAGATATCTGAATATCCATTCTTTCTTTAGCACTCTTGG } \\
* * * * * * * * * * * * * * * * * * * * * * * * * * * * * * * * * * * * * * * * * * * * * * * * *\end{array}$ & 344 \\
\hline AF453357 & ATTACTGACAGCTTGTAGGTTGCTGCCCTTGGCAGAGCCGCAGAAGCAAT & 498 \\
\hline Sample_A & ATTACTGACAGCTTGTAGGTTGCTGCCCTTGGCAGAGCCGCAGAAGCAAT & 463 \\
\hline Lodoicea_maldivica_RM & ATTACTGACAGCTTGTAGGTTGCTGCCCTTGGCAGAGCCGCAGAAGCAAT & 394 \\
\hline & $* * * * * * * * * * * * * * * * * * * * * * * * * * * * * * * * * * * * * * * * * * * * * * * * * *$ & \\
\hline AF453357 & ATGCTGATGTCGTAATCGAAGTTTTACCGACACAATTAATTCCTGGTGAC & 548 \\
\hline Sample_A & ATGCTGATGTCGTAATCGAAGTTTTACCGACACAATTAATTCCTGGTGAC & 513 \\
\hline Lodoicea_maldivica_RM & 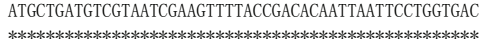 & 444 \\
\hline AF453357 & AAAGAAAGGAAGGTGCTGAGAGTTCGATTGGTGATGCAAGAAGGGGTGAA & 598 \\
\hline Sample_A & AAAGAAAGGAAGGTGCTGAGAGTTCGA-_- & 540 \\
\hline Lodoicea_maldivica_RM & $\begin{array}{l}\text { AAAGAAAGGAAG---- } \\
* * * * * * * * * * *\end{array}$ & 456 \\
\hline
\end{tabular}

Figure 1 Sequences alignment for Lodoicea maldivica reference material (RM) [GenBank: JF820816], Sample A and [GenBank: AF453357]. homology (Figure 2), it matched the PRK sequence of species Cocos nucifera with 100\% homology in GenBank database [GenBank: HQ265608] (Figure 3). Currently, there is only one single entry of the Lodoicea maldivica PRK gene sequence in NCBI GenBank [GenBank: AF453357]. The sequence was obtained from a Lodoicea maldivica voucher (voucher number: C.E. Lewis 98-020/ $\mathrm{BH})$ and reported by Lewis et al. in 2002 [12]. However, the exact source of the voucher was not reported. The BLAST [15] result of the Lodoicea maldivica reference material sequence obtained in this study showed a $99 \%$ homology to that of the [GenBank: AF453357] (Figure 1). The Lodoicea maldivica reference species used in this study was obtained from the country of origin of the species with official certificate. The present study provides an alternative source of nucleotide sequence data for GenBank for the identification of Lodoicea maldivica. The applicability and accuracy of the method have been demonstrated by the consistent results obtained from replicated analysis of the samples.

\section{Conclusion}

A new molecular method for the identification of Lodoicea maldivica seeds in fresh, frozen or dried forms was developed.

\begin{tabular}{|c|c|}
\hline $\begin{array}{l}\text { Lodoicea_maldivica_RM } \\
\text { Sample_H }\end{array}$ & CCCGGAAGCTCGACTTTGATGCTTATGTTGGTATGTCACCTTGCCAAAGC \\
\hline $\begin{array}{l}\text { Lodoicea_maldivica_RM } \\
\text { Sample_H }\end{array}$ & $\begin{array}{r}\text { ACCTAGTTTGTTGGTACTTGAAGAATTGGCAGAGCTATAATTTGTTGGTA } \\
* * * * * * * * * * * * * * *\end{array}$ \\
\hline $\begin{array}{l}\text { Lodoicea_maldivica_RM } \\
\text { Sample_H }\end{array}$ & 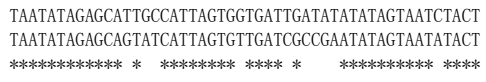 \\
\hline $\begin{array}{l}\text { Lodoicea_maldivica_RM } \\
\text { Sample_H }\end{array}$ & 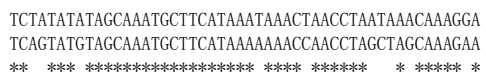 \\
\hline $\begin{array}{l}\text { Lodoicea_maldivica_RM } \\
\text { Sample_H }\end{array}$ & 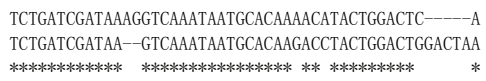 \\
\hline $\begin{array}{l}\text { Lodoicea_maldivica_RM } \\
\text { Sample_H }\end{array}$ & 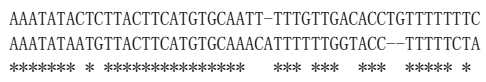 \\
\hline $\begin{array}{l}\text { Lodoicea_maldivica_RM } \\
\text { Sample_H }\end{array}$ & 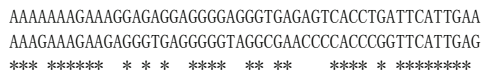 \\
\hline $\begin{array}{l}\text { Lodoicea_maldivica_RM } \\
\text { Sample_H }\end{array}$ & $\begin{array}{l}\text { ATAATGAGACAAGTAGTTATGTTGCATCTCATGTTCTTCAGATATCTGAA } \\
\text { ATAATGAGACAATTAGATATGCTGAGTCTTAT-- } \\
* * * * * * * * * * * * * * * * * * * * * * * * * * * * * * * * * * *\end{array}$ \\
\hline $\begin{array}{l}\text { Lodoicea_maldivica_RM } \\
\text { Sample_H }\end{array}$ & 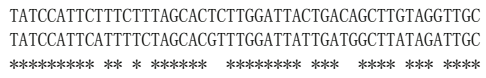 \\
\hline $\begin{array}{l}\text { Lodoicea_maldivica_RM } \\
\text { Sample_H }\end{array}$ & $\begin{array}{l}\text { TGCCCTTGGCAGAGCCGCAGAAGCAATATGCTGATGTCGTAATCGAAGTT } \\
\text {-GACCCTGGCAGACCCACAGAAGCAATATGCTGATGTCGTAATTGAAGTT } \\
* * * * * * * * * * * * * * * * * * * * * * * * * * * * * * * * * * * * * * * * * *\end{array}$ \\
\hline $\begin{array}{l}\text { Lodoicea_maldivica_RM } \\
\text { Sample_H }\end{array}$ & $\begin{array}{l}\text { TTACCGACACAATTAATTCCTGGTGACAAAGAAAGGGAG- } \\
\text { TTACCGACACAATTAATTCCTGATGACAATGAAAGGAAGGTGCTGAGAGT } \\
* * * * * * * * * * * * * * * * * * * * * * * * * * * * * * * * * *\end{array}$ \\
\hline
\end{tabular}

Figure 2 Sequences alignment for Lodoicea maldivica reference material (RM) [GenBank: JF820816] and Sample H. 


\begin{tabular}{|c|c|}
\hline \multirow{2}{*}{$\begin{array}{l}\text { HQ265608 } \\
\text { Sample_H }\end{array}$} & \multirow{2}{*}{$\begin{array}{c}\text { TTTGTGATATGGGAGAACGTGGGCACAGTCTCGAAAGCATCAAAGCTAGCATCGAAGCCC } 60 \\
\text { * } 3 * 0\end{array}$} \\
\hline & \\
\hline HQ265608 & GGAAGCTCGACTTTGATGCTTATGTTGGTATGTCACCTTGCCAAAGCACCTAGTTTGTTG 120 \\
\hline Sample_H & $\begin{array}{l}\text { GGAAGCTCGACTTTGATGCTTATGTTGGTATGTCACCTTCCAAAGCACCTAGTTTGTTG } 63 \\
* * * * * * * * * * * * * * * * * * * * * * * * * * * * * * * * * * * * * * * * * * * * * * * * * * * * * * * * * * * *\end{array}$ \\
\hline HQ265608 & GTACTTGAAGAATTGGCAGAGCTATAATTTGTTGGTATAATATAGAGCAGTATCATTAGT 180 \\
\hline Sample_H & $\begin{array}{l}\text { GTACTTGAAGAATTGGCAGAGCTATAATTTGTTGGTATAATATAGAGCAGTATCATTAGT } 123 \\
* * * * * * * * * * * * * * * * * * * * * * * * * * * * * * * * * * * * * * * * * * * * * * * * * * * * * * * * * * 10\end{array}$ \\
\hline HQ265608 & GTTGATCGCCGAATATAGTAATATACTTCAGTATGTAGCAAATGCTTCATAAAAAAACCA 240 \\
\hline Sample_H & $\begin{array}{l}\text { GTTGATCGCGAATATAGTAATATACTTCAGTATGTAGCAAATGCTTCATAAAAAAACCA } 183 \\
* * * * * * * * * * * * * * * * * * * * * * * * * * * * * * * * * * * * * * * * * * * * * * * * * * * * * * * * * *\end{array}$ \\
\hline HQ265608 & ACCTAGCTAGCAAAGAATCTGATCGATAAGTCAAATAATGCACAAGACCTACTGGACTGG 300 \\
\hline Sample_H & $\begin{array}{l}\text { ACCTAGCTAGCAAAGAATCTGATCGATAAGTCAAATAATGCACAAGACCTACTGGACTGG } 243 \\
* * * * * * * * * * * * * * * * * * * * * * * * * * * * * * * * * * * * * * * * * * * * * * * * * * * * * * * *\end{array}$ \\
\hline HQ265608 & ACTAAAAATATAATGTTACTTCATGTGCAAACATTTTTTGGTACCTTTTTCTAAAAGAAA 360 \\
\hline Sample_H & $\begin{array}{l}\text { ACTAAAAATATAATGTTACTTCATGTGCAACATTTTTGGTACCTTTTTCTAAAGGAA } 303 \\
* * * * * * * * * * * * * * * * * * * * * * * * * * * * * * * * * * * * * * * * * * * * * * * * * * * * * *\end{array}$ \\
\hline HQ265608 & GAAGAGGGTGAGGGGGTAGGCGAACCCCACCCGGTTCATTGAGATAATGAGACAATTAGA 420 \\
\hline Sample_H & $\begin{array}{l}\text { GAAGAGGGTGAGGGGTAGGCGAACCCCACCCGGTTCATTGAGATAATGAGACAATTAGA } 363 \\
* * * * * * * * * * * * * * * * * * * * * * * * * * * * * * * * * * * * * * * * * * * * * * * * * * * * * * *\end{array}$ \\
\hline HQ265608 & TATGCTGAGTCTTATACATATCAGAATATCCATTCATTTTCTAGCACGTTTGGATTATTG 480 \\
\hline Sample_H & $\begin{array}{l}\text { TATGCTGAGTCTTATACATATCAGAATATCCATTCATTTCTAGCACGTTTGGATTATTG } \\
* * * * * * * * * * * * * * * * * * * * * * * * * * * * * * * * * * * * * * * * * * * * * * * * * * * * * * * * * * * *\end{array}$ \\
\hline HQ265608 & ATGGCTTATAGATTGCGACCCTGGCAGACCCACAGAAGCAATATGCTGATGTCGTAATTG 540 \\
\hline Sample_H & $\begin{array}{l}\text { ATGGCTTATAGATTGCGACCCTGGCAGACCCACAGAAGCAATATGCTGATGTCGTAATTG } 483 \\
* * * * * * * * * * * * * * * * * * * * * * * * * * * * * * * * * * * * * * * * * * * * * * * * * * * * * * * * * * 6\end{array}$ \\
\hline HQ265608 & AAGTTTTACCGACACAATTAATTCCTGATGACAATGAAAGGAAGGTGCTGAGAGTTCGAT 600 \\
\hline Sample_H & $\begin{array}{l}\text { AAGTTTTACCGACACAATTAATTCCTGATGACAATGAAAGGAAGGTGCTGAGAGTTCGAT } 543 \\
* * * * * * * * * * * * * * * * * * * * * * * * * * * * * * * * * * * * * * * * * * * * * * * * * * * * * * * * * * * * * *\end{array}$ \\
\hline HQ265608 & TGGTGATGAAAGAAGGGGTGAAGTACTTCAATCCGGTTTACCTCTTCGACGAAGGCTCCA 660 \\
\hline Sample_H & $\begin{array}{l}\text { TGGTGATGAAAGAAGGGGTGAAGTACTTCAATCCGGTTTACCTCTTCGACGAAGGCTCCA } 603 \\
* * * * * * * * * * * * * * * * * * * * * * * * * * * * * * * * * * * * * * * * * * * * * * * * * * * * * * * *\end{array}$ \\
\hline HQ265608 & CTGTTTCATGGATACCCTGCGGNAGGAAACTAAGCTGCTCATCCCC 706 \\
\hline Sample_H & $\begin{array}{l}\text { CTGTTTCATGGATACCCTGCGGTAGGAAACTAAGCTGCTCAT--- } 645 \\
* * * * * * * * * * * * * * * * * * * * * * * * * * * * * * * * * * * * * *\end{array}$ \\
\hline Figur & $\begin{array}{l}\text { quences alignment for Sample } \mathbf{H} \text { and } \\
\text { Sank: HQ265608]. }\end{array}$ \\
\hline
\end{tabular}

\section{Disclaimers}

This article does not necessarily reflect the views of the Government of the HKSAR. The mentions of trade names or commercial products do not constitute any endorsement or recommendations.

\section{Abbreviations}

CITES: Convention on International Trade in Endangered Species of Wild Fauna and Flora; CTAB: hexadecyl trimethylammonium bromide; DMSO: Dimethyl sulfoxide; EDTA: Ethylenediaminetetraacetic acid; NCBI: National Center for Biotechnology Information; PCR: polymerase chain reaction; PRK: phosphoribulokinase; PVP: polyvinylpolypyrrolidone.

\section{Acknowledgements}

The authors would like to thank Dr CM Lau, Government Chemist of the Government Laboratory of the HKSAR, China, for his support and encouragement during the study. We would also like to thank Dr Della WM Sin and Ms Silvia YK Tam for their discussion and comments.

\section{Authors' contributions}

CYM conceived and designed the study, collected the samples, performed the laboratory work, analyzed and interpreted the data, and drafted the manuscript. CSM supervised the project and finalized the manuscript. Both authors read and approved the final version of the manuscript.

\section{Competing interests}

The authors declare that they have no competing interests.

Received: 17 June 2011 Accepted: 30 September 2011

Published: 30 September 2011

\section{References}

1. Palm and Cycad Societies of Australia. [http://www.pacsoa.org.au/palms/ Lodoicea/index.html].

2. The Convention on International Trade in Endangered Species of Wild Fauna and Flora. [http://www.cites.org/].

3. Hu SY: Food Plants of China. The Chinese University Press; 2005.

4. Hirao T, Imai S, Sawada H, Shiomi N, Hachimura S, Kato H: PCR Method for Detecting Trace Amounts of Buckwheat (Fagopyrum spp.) in Food. Biosci Biotechnol Biochem 2005, 69:724-731.

5. Taberlet P, Gielly L, Pautou G, Bouvet J: Universal primers for amplification of three non-coding regions of chloroplast DNA. Plant Mol Biol 1991, 17:1105-1109.

6. Hills DM, Dixon MT: Ribosomal DNA: molecular evolution and phylogenetic inference. Q Rev Biol 1991, 66:411-453.

7. Soltis PS, Soltis DE, Smiley CJ: An rbcL sequence from a Miocene Taxodium (bald cypress). Proc Natl Acad Sci USA 1992, 89:449-451.

8. Savolainen V, Cuénoud P, Spichiger R, Martinez MDP, Crèvecoeur M, Manen J-F: The use of herbarium specimens in DNA phylogenetics: evalution and improvement. Plant Syst Evol 1995, 197:87-98.

9. Baker WJ, Asmussen CB, Barrow SC, Dransfield J, Hedderson TA: A phylogenetic study of the palm family (Palmae) based on chloroplast DNA sequences from the trnL-trnF region. Plant Syst Evol 1999, 219:111-126.

10. Loo AHB, Dransfield J, Chase MW, Baker WJ: Low-copy nuclear DNA, phylogeny and the evolution of dichogamy in the betel nut palms and their relatives (Arecinae; Arecaceae). Mol Phylogenet Evol 2006, 39:598-618.

11. Thomas MM, Garwood NC, Baker WJ, Henderson SA, Russell SJ, Hodel DR, Bateman RM: Molecular phylogeny of the palm genus Chamaedorea, based on the low-copy nuclear genes PRK and RPB2. Mol Phylogenet Evol 2006, 38:398-415.

12. Lewis CE, Doyle JJ: A phylogenetic analysis of tribe Areceae (Arecaceae) using two low-copy nuclear genes. Plant Syst Evol 2002, 236:1-17.

13. Cuenca A, Asmussen-Lange CB, Borchsenius F: A dated phylogeny of the palm tribe Chamaedoreeae supports Eocene dispersal between Africa, North and South America. Mol Phylogenet Evol 2008, 46:760-775.

14. Foodstuffs-Methods of analysis for the detection of genetically modified organisms and derived products-Quantitative nucleic acid based methods. 2005, ISO 21571.

15. National Center for Biotechnology Information. [http://blast.ncbi.nlm.nih. gov/Blast.cgi].

16. European Bioinformatics Institute. [http://www.ebi.ac.uk/Tools/].

17. Angeles JGC, Laurena AC, Tecson-Mendoza EM: Extraction of Genomic DNA From the Lipid-, Polysaccharide-, and Polyphenol- Rich Coconut (Cocos nucifera L.). Plant Mol Biol Rep 2005, 23:297a-297i.

doi:10.1186/1749-8546-6-34

Cite this article as: Mak and Mok: Molecular identification of Lodoicea

maldivica (coco de mer) seeds. Chinese Medicine 2011 6:34

\section{Submit your next manuscript to BioMed Central and take full advantage of:}

- Convenient online submission

- Thorough peer review

- No space constraints or color figure charges

- Immediate publication on acceptance

- Inclusion in PubMed, CAS, Scopus and Google Scholar

- Research which is freely available for redistribution 